\title{
Hasil Diagnostik Mycobacterium tuberculosis pada Penderita Batuk $\geq 2$ Minggu dengan Pewarnaan Ziehl-Neelsen Di Poliklinik DOTS RSUP Prof. Dr. R. D. Kandou Manado
}

\author{
${ }^{1}$ Henry W. J. Janis \\ ${ }^{2}$ John Porotu'o \\ ${ }^{2}$ Fredine E. S. Rares
}

\author{
${ }^{1}$ Program Studi Pendidikan Dokter Fakultas Kedokteran Universitas Sam Ratulangi Manado \\ ${ }^{2}$ Bagian Mikrobiologi Kedokteran Universitas Sam Ratulangi Manado \\ Email: janishenry10@gmail.com
}

\begin{abstract}
Cough is a defence mechanism in the respiratory tract, however, cough for $\geq 2$ weeks is a pathognomonic sign in tuberculosis (TB) cases. Tuberculosis is an infectious disease caused by Mycobacterium tuberculosis. In Indonesia, the number of TB cases has been increasing from year to year. This study was aimed to determine the profile of $M$. tuberculosis in patients with cough $\geq 2$ weeks in Polyclinic DOTS Prof. Dr. R. D. Kandou Manado Hospital. This was a descriptive study with a cross sectional design. In the period from October to November 2017 there were 191 patients with cough $\geq 2$ weeks, males (121 patients; $63 \%$ ) were more common than females (70 patients; 37\%) patients, most were in the age group $>65$ years old (27\%). Examination of acid-fast bacteria in patients' sputum revealed 44 (23\%) patients with positive acid-fast bacteria consisting of 33 males $(75 \%)$ and 11 females (25\%); most (25\%) were 45-54 years old. Conclusion: Most patients with positive acid-fast bacteria were males and in the age group of 45-54 years old.
\end{abstract}

Keywords: Mycobacterium tuberculosis, Tuberculosis, Ziehl-Neelsen

\begin{abstract}
Abstrak: Batuk merupakan mekanisme pertahanan di saluran napas namun batuk $\geq 2$ minggu merupakan gejala khas yang ditemukan pada penderita tuberkulosis (TB). Tuberkulosis adalah suatu penyakit menular yang disebabkan oleh Mycobacterium tuberculosis. Di Indonesia kasus tuberkulosis menunjukkan peningkatan dari tahun ke tahun. Penelitian ini bertujuan untuk mengetahui gambaran bakteri $M$. tuberculosis pada penderita batuk $\geq 2$ minggu di Poliklinik DOTS RSUP Prof. Dr. R. D. Kandou Manado. Jenis penelitian ialah deskriptif dengan desain potong lintang. Hasil penelitian pada periode pengambilan sampel Oktober sampai November 2017 mendapatkan 191 pasien batuk $\geq 2$ minggu di Poliklinik DOTS RSUP Prof. Dr. R. D. Kandou Manado, laki-laki (121 pasien; 67\%) lebih banyak daripada perempuan (70 pasien; $33 \%$ ) dengan usia terbanyak $>65$ tahun (27\%). Pada pemeriksaan BTA dalam sputum pasien ditemukan 44 (23\%) pasien dengan BTA positif, paling banyak pada laki-laki yaitu 33 pasien (75\%) dibandingkan perempuan 11 pasien (25\%), terbanyak pada usia 45-54 tahun yaitu 11 pasien (25\%). Simpulan: Pada penelitian ini didapatkan 23\% kasus dengan Mycobacterium tuberculosis positif, terbanyak pada laki-laii dan kelompok usia 45-54 tahun.
\end{abstract}

Kata kunci: Mycobacterium tuberculosis, tuberkulosis, Ziehl-Neelsen

Batuk merupakan mekanisme pertahanan tubuh di saluran pernafasan dan merupakan gejala suatu penyakit atau reaksi tubuh terhadap iritasi di tenggorokan karena adanya lendir atau mukus, makanan, debu, asap dan sebagainya. Keberadaan mukus pada saluran pernafasan membantu melindungi paru-paru dengan menjebak partikel asing yang masuk ke saluran pernapasan. ${ }^{1}$

Gejala batuk $\geq 2$ minggu merupakan 
gejala khas yang ditemukan pada penderita tuberculosis (TB). Tuberkulosis adalah suatu penyakit menular yang disebabkan oleh kuman dari kelompok Mycobaterium yaitu Mycobacterium tuberculosis. ${ }^{2}$ Kuman ini dapat menyerang berbagai organ tetapi yang paling sering ialah paru-paru. ${ }^{3}$ Mycobacterium tuberculosis dapat menular melalui satu orang ke orang lain lewat percikan air liur ataupun dahak yang terbawa oleh udara dari batuk. ${ }^{4}$

Tuberkulosis merupakan salah satu ancaman berbahaya dalam dunia kesehatan. Menurut laporan World Health Organization (WHO) pada tahun 2016, TB masuk dalam 10 besar penyakit penyebab kematian terbanyak di dunia dengan jumlah kematian sebanyak 1,8 juta orang per tahun termasuk 400.000 orang dengan HIV positif. Terdapat sekitar 10,4 juta kasus baru TB yang terjadi di seluruh dunia selama tahun 2015. Untuk kawasan Asia Tenggara terdapat sebanyak 710.000 kematian akibat TB, dengan jumlah kasus yang ternotifikasi ialah 2.656.560 kasus. Indonesia termasuk dalam 6 besar negara dengan angka kasus TB sebesar $60 \%$ di dunia bersama dengan China, India, Nigeria, Pakistan, dan Afrika Selatan dengan total kasus yang dilaporkan sebanyak 330.729 kasus. ${ }^{5}$ Terdapat 181.711 kasus baru TB paru dengan BTA positif yang terjadi di Indonesia menurut Pusat Data dan Informasi Kementrian Kesehatan RI tahun 2016. Berdasarkan data yang sudah disampaikan tadi kasus TB paling banyak didapatkan pada usia 45-54 yaitu 19,82\% dan pada usia 25-34 yaitu 19,69\%. ${ }^{6}$ Di Provinsi Sulawesi Utara pada tahun 2016 jumlah kasus baru TB paru dengan BTA positif ialah sebanyak 4.229 kasus ${ }^{6}$. Untuk Kota Manado sendiri terdapat 1.358 kasus TB yang ditemukan. ${ }^{7}$

Penelitian oleh Ramalia ${ }^{8}$ terhadap 25 pasien dengan batuk $\geq 2$ minggu yang terdiri dari 7 pasien di Puskesmas Ranomuut Manado dan 18 pasien di Puskesmas Kombos Manado. Batuk $\geq 2$ minggu lebih banyak terjadi pada laki-laki (68\%) dan distribusi kasus berdasarkan kelompok usia banyak terjadi pada kelompok usia 15-34 tahun (44\%) diikuti 35-54 tahun (40\%) . Hasil pemeriksaan BTA ditemukan 2 pasien dengan BTA postif dalam sputum

Sejalan dengan penelitian Domu et al. ${ }^{9}$ ditemukan 28 sampel di Puskesmas Tuminting Manado dan 2 sampel di Puskesmas Tongkaina Manado. Distribusi sampel berdasarkan jenis kelamin ditemukan batuk $\geq 2$ minggu banyak terjadi pada perempuan $(57 \%)$ dibandingkan laki-laki (43\%) sedangkan untuk kelompok usia tersering ialah kelompok usia 35-54 (56,7\%) tahun, diikuti usia 15-34 tahun (30\%). Hasil pemeriksaan BTA ditemukan 2 sampel BTA positif dalam sputum.

Tuberkulosis yang tidak diobati akan menyebabkan Mycobacterium tuberculosis tinggal dalam paru dan menyebar keseluruh tubuh sehingga menyebabkan berbagai komplikasi pada paru, yaitu atelektasis, hemoptisis, fibrosis, bronkiektasis, pneumotoraks, dan, gagal nafas yang menimbulkan gejala seperti batuk berdahak, nyeri dada saat bersin dan batuk, batuk berdarah, demam, keringat di malam hari, hilangnya nafsu makan yang menyebabkan penurunan berat badan, bahkan kematian. $^{10,11}$

Berdasarkan penelitian dari Puspitasari ${ }^{12}$ ditemukan sebanyak 52 pasien yang mendapat pengobatan TB di Poliklinik Paru RSUP Prof. Dr. R.D. Kandou Manado pada periode Oktober-Desember 2013 dan berdasarkan data dari Poliklinik DOTS diketahui terdapat 303 kunjungan suspek TB selama periode waktu AgutusSeptember 2017 di RSUP Prof. Dr. R.D. Kandou Manado.

\section{METODE PENELITIAN}

Jenis penelitian ini ialah deskriptif eksperimental dengan desain potonglintang. Pengambilan sampel dilakukan pada periode Oktober-November 2017 di Poliklinik DOTS RSUP Prof. Dr. R. D. Kandou Manado. Pemeriksaan sampel dilakukan di Laboratorium Mikrobiologi Fakultas Kedokteran Universitas Sam Ratulangi Manado dan di Laboratorium Mikrobiologi RSUP Prof. Dr. R. D. Kandou Manado. 


\section{HASIL PENELITIAN}

Pada penelitian ini ditemukan 191 pasien dengan batuk $\geq 2$ minggu. Tabel 1 menunjukkan pasien dengan batuk $\geq 2$ minggu lebih banyak ditemukan pada lakilaki (63\%) dibandingkan perempuan $(37 \%)$.

Tabel 1. Distribusi pasien berdasarkan jenis kelamin

\begin{tabular}{ccc}
\hline $\begin{array}{c}\text { Jenis } \\
\text { kelamin }\end{array}$ & Jumlah & $\begin{array}{c}\text { Persentase } \\
(\mathbf{\%})\end{array}$ \\
\hline Laki-Laki & 121 & $63 \%$ \\
Perempuan & 70 & $37 \%$ \\
Total & 191 & $100 \%$ \\
\hline
\end{tabular}

Tabel 2 menunjukan usia $>65$ tahun (25\%) merupakan usia yang terbanyak ditemukan pada pasien dengan batuk $\geq 2$ minggu.

Tabel 2. Distribusi pasien berdasarkan usia

\begin{tabular}{ccc}
\hline Usia & Jumlah & Persentase \\
\hline $15-24$ & 22 & $12 \%$ \\
$25-34$ & 19 & $10 \%$ \\
$35-44$ & 18 & $9 \%$ \\
$45-54$ & 40 & $21 \%$ \\
$55-64$ & 40 & $21 \%$ \\
$>65$ & 52 & $27 \%$ \\
Total & 191 & $100 \%$ \\
\hline
\end{tabular}

Pada Tabel 3 ditemukan kuman BTA positif dalam sputum penderita batuk $\geq 2$ minggu sebanyak 44 orang $(23 \%)$.

Tabel 3. Hasil pemeriksaan BTA

\begin{tabular}{ccc}
\hline $\begin{array}{c}\text { Hasil } \\
\text { pemeriksaan }\end{array}$ & Jumlah & Persentase \\
\hline BTA (+) & 44 & $23 \%$ \\
BTA(-) & 147 & $77 \%$ \\
Total & 191 & $100 \%$ \\
\hline
\end{tabular}

Tabel 4 menunjukan hasil BTA positif lebih banyak ditemukan pada laki-laki (75\%) dibandingkan perempuan (25\%).

Tabel 5 menunjukkan kelompok usia 45-54 tahun merupakan usia yang terbanyak $(25 \%)$ ditemukan pada pasien dengan hasil BTA positif.

Tabel 4. Distribusi hasil pemeriksaan BTA positif berdasarkan jenis kelamin.

\begin{tabular}{ccc}
\hline $\begin{array}{c}\text { Jenis } \\
\text { kelamin }\end{array}$ & Jumlah & Persentase \\
\hline Laki-laki & 33 & $75 \%$ \\
Perempuan & 11 & $25 \%$ \\
Total & 44 & $100 \%$ \\
\hline
\end{tabular}

Tabel 5. Distribusi hasil pemeriksaan BTA positif berdasarkan kelompok usia.

\begin{tabular}{ccc}
\hline Usia & Jumlah & Persentase \\
\hline $15-24$ & 8 & $18 \%$ \\
$25-34$ & 4 & $9 \%$ \\
$35-44$ & 6 & $14 \%$ \\
$45-54$ & 11 & $25 \%$ \\
$55-64$ & 10 & $23 \%$ \\
$>65$ & 5 & $11 \%$ \\
Total & 44 & $100 \%$ \\
\hline
\end{tabular}

\section{BAHASAN}

Penelitian ini dilakukan pada pasien yang menderita batuk $\geq 2$ minggu di Poliknik DOTS RSUP Prof. Dr. R.D. Kandou Manado. Periode pengambilan sampel pada bulan Oktober-November 2017. Pemeriksaan yang dilakukan ialah pemeriksaan mikrobiologi dengan teknik pewarnaan Ziehl-Neelsen di Laboratorium Mikrobiologi Fakultas Kedokteran Universitas Sam Ratulangi Manado dan di Laboratorium Mikrobiologi RSUP Prof. Dr. R. D. Kandou Manado.

Berdasarkan distribusi kasus batuk $\geq 2$ minggu menurut jenis kelamin ditemukan lebih banyak pada laki-laki yaitu 121 pasien $(63 \%)$ dengan hasil pemeriksaan BTA yang positif pada 33 sampel (75\%) dibandingkan perempuan yaitu 70 sampel (37\%) dengan hasil pemeriksaan BTA yang positif pada 11 sampel (25\%). Hasil penelitian ini sejalan dengan penelitian Susanti et al. ${ }^{4}$ yang dilakukan pada tahun 2015 di Poliklinik Penyakit Dalam RSUP Prof. Dr. R. D. Kandou Manado yng mendapatkan terbanyak pada laki-laki yaitu 15 kasus $(65,2 \%)$ dibandingkan pada 
perempuan 8 kasus $(34,8 \%)$. Sejalan juga dengan penelitian dari Sari et al. ${ }^{13}$ di Jakarta yang mendapatkan bahwa pasien terbanyak ialah laki-laki dengan usia 18-35 tahun sebanyak 17 sampel $(51,5 \%)$. Berbeda dengan penelitian Domu et al. ${ }^{9}$ di Puskesmas Tuminting dan Tongkaina yang mendapatkan terbanyak pada perempuan 17 kasus (57\%) sedangkan pada laki-laki sebanyak 13 kasus (43\%).

Banyaknya jumlah kejadian TB pada laki-laki disebabkan karena faktor perilaku dimana laki-laki lebih banyak yang merokok dan mengomsumsi alcohol. Nikotin yang terkandung dalam rokok menghambat produksi Tumor Necrosis Factor Alfa (TNF- $\alpha$ ) di makrofag pada paru-paru dimana sitokin ini memilki fungsi meningkatkan fagositosis makfrofag dan menginduksi apoptosis makrofag yang terinfeksi bakteri tersebut. TNF- $\alpha$ berperan dalam menjaga integritas dari granuloma yang terbentuk untuk mengisolasi bakteri $M$. tuberculosis oleh makrofag sehingga jika $\mathrm{TNF} \alpha$ terhambat produksinya akan menyebabkan perokok lebih rentan terinfeksi karena Mycobacterial load akan menjadi sangat cepat dan pembentukan granuloma akan terhambat. ${ }^{14-16}$

Di Indonesia sendiri risiko bagi lakilaki untuk menderita TB ialah 1,6 kali lebih banyak daripada perempuan. ${ }^{17}$ Berdasarkan hasil penelitian Munir et al. ${ }^{18}$ ditemukan bahwa perempuan lebih sering terlambat datang ke pelayanan kesehatan. Hal ini berhubungan dengan aib dan rasa malu yang dirasakan pada perempuan lebih besar daripada laki-laki dan adanya kekhwatiran akan dikucilkan oleh keluarga dan lingkungannya serta adanya hambatan ekonomi dan faktor sosial budaya. Ditemukan juga bahwa laki-laki pergi ke pelayanan kesehatan ketika mereka mengetahui pengobatan TB gratis. ${ }^{18}$

Distribusi kasus berdasarkan kelompok usia pasien batuk $\geq 2$ minggu ditemukan banyak terjadi pada usia $>65$ tahun yaitu sebanyak 52 sampel (27\%) dan berikutnya pada usia 45-54 tahun dan 55-64 tahun sebanyak 40 sampel (21\%) dengan hasil pemeriksaan BTA positif terbanyak pada kelompok usia 45-54 sejumlah 11 (25\%) sampel diikuti dengan kelompok usia 55-64 tahun sebanyak 10 sampel (23\%). Banyaknya kasus batuk $\geq 2$ minggu pada usia >65 tahun dapat disebabkan oleh meningkatnya angka harapan hidup sehingga menyebabkan adanya peningkatan populasi orang berusia tua, namun orang tua lebih rentan untuk terinfeksi TB ataupun penyakit infeksi lainnya karena penurunan sistem imun yang disebabkan oleh peningkatan faktor komorbiditas TB pada orang usia tua seperti penyakit kronis (misalnya diabetes dan penyakit paru kronis) atau terapi imunosupresif (pada artritis, transplantasi organ atau kanker) serta age-related immune-senescence. Hal ini juga dapat disebabkan karena keterbatasan mobilitas pada orang tua, faktor ekonomi yang rendah, kesehatan lingkungan yang buruk, sehingga menyebabkan suspek TB banyak pada orang usia tua. ${ }^{19,20}$

Ditemukannya hasil BTA positif terbanyak pada kelompok usia 45-54 (25\%) diikuti dengan kelompok usia 55-64 (23\%) tahun ini sesuai dengan dengan data dari pusat data dan informasi informasi dari Kemenkes RI $^{6}$ tahun 2016 yang melaporkan jumlah penderita TB terbanyak pada kelompok usia 45-54 tahun (19,82\%). Demikian pula halnya dengan penelitian dari ukmini dan Chatarina ${ }^{17}$ yang mendapatkan bahwa suspek TB terbanyak pada kelompok usia 35-54 tahun (48,7\%). Usia 45-54 tahun sendiri masih termasuk usia produktif dimana seseorang lebih sering melakukan kegiatan seperti berinteraksi dengan banyak orang namun kelompok usia 45-54 tahun ini juga termasuk dalam usia transisi dari produktif ke usia tua dimana akan terjadi penurunan sistem imun karena penuaan sehingga risiko untuk terkena TB menjadi lebih besar. ${ }^{16,20}$ Berdasarkan penelitian yang dilakukan oleh Negin et al. ${ }^{19}$ yang menemukan adanya peningkatan angka kejadian TB pada orang yang berusia 50 tahun ke atas di negera berpenghasilan rendah dan menengah, berdasarkan survei dari DisabillityAdjusted Life Years (DALYs) di Asia Tenggara dari 9 juta pasien TB dilakukan 
penelitian ditemukan 4,4 juta pasien TB dengan usia $>50$ tahun. Berdasarkan data Global Burden of Disease Study tahun 2015 angka kematian penderita TB pada usia di atas 50 tahun sebesar $62 \%$. Biasanya angka penderita TB pada usia di atas 50 tahun paling banyak di negara dengan pendapatan tinggi seperti Amerika dan Australia dan rendah di negara dengan pendapatan rendah dan menengah termasuk Indonesia. ${ }^{20}$ Hasil penelitian ini berbanding terbalik dengan penelitian sebelumnya oleh Ramalia $^{8}$ di Puskesmas Ranomuut dan Puskesmas Kombos Manado yang melaporkan kasus batuk $>2$ minggu terbanyak pada kelompok umur 15-34 tahun (44\%).

Berdasarkan disitribusi hasil pemeriksaan BTA, didapatkan BTA positif sebanyak 44 sampel (23\%) dan untuk BTA negatif sebanyak 147 sampel $(77 \%)$. Dari data tahun 2015 di Poliklinik DOTS RSUP Prof. Dr. R. D. Kandou Manado ditemukan $312(13,3 \%)$ kasus BTA positif dari 2342 suspek, sedangkan pada data tahun 2016 ditemukan 497 (19,2\%) kasus BTA positif dari 2584 suspek. Berdasarkan data tersebut dapat dilihat adanya peningkatan kasus BTA positif di Poliklinik DOTS RSUP Prof. Dr. R.D Kandou Manado. Karena penelitian yang dilakukan oleh peneliti memiliki waktu singkat maka hasil dan persentase yang ada belum dapat menjadi acuan adanya peningkatan pasien dengan BTA positif di Poliklinik DOTS RSUP Prof. Dr. R. D. Kandou Manado selama tahun 2017. Pada tahun 2016 di Indonesia ditemukan jumlah kasus baru BTA positif sebanyak 351.893 kasus, meningkat bila dibandingkan dengan semua kasus tuberkulosis yang ditemukan pada tahun 2015 yaitu sebanyak 330.729 kasus. Untuk angka keberhasilan pengobatan TB (succes rate) tahun 2016 Indonesia mencapai $85,1 \%$ sedangkan target yang diharapkan untuk angka keberhasilan pengobatan untuk tahun 2016 ialah $>90 \%$. Angka keberhasilan pengobatan TB untuk Provinsi Sulawesi Utara tahun 2016 masih belum mencapai target yaitu hanya $89,3 \%$, berbeda dengan angka capaian keberhasilan pengobatan TB tahun 2015 dimana Provinsi Sulawesi Utara mampu mencapai angkah 94\%. ${ }^{6}$

Meningkatnya kasus TB pada awal tahun 1990-an menyebabkan WHO dan IUALTD mengembangkan strategi yang dikenal sebagai srategi DOTS (Directly Observed Treatment Short-Course). Fokus utama dari terapi DOTS ialah penemuan dan penyembuhan pasien. Indonesia merupakan salah satu negara high burden dan sedang menggalakan strategi DOTS. Salah satu komponen strategi ini ialah pemeriksaan mikroskopik yang bermutu, dan pemeriksaan TB dengan pewarnaan ZiehlNeelsen ialah baku emas untuk pemeriksaan BTA, karena teknik pewarnaan ZiehlNeelsen memiliki metode yang sederhana namun memberikan sensitivitas dan spesifitas yang cukup tinggi sehingga diharapkan dengan strategi DOTS ini dapat mengurangi angka kejadian TB hingga $>90 \%$ di ditahun 2035 sesuai dengan resolusi WHO., ${ }^{2,21}$

\section{SIMPULAN}

Dari hasil penelitian terhadap pasien yang menderita batuk $\geq 2$ minggu di Poliklinik DOTS RSUP Prof. Dr. R. D. Kandou Manado didapatkan 44 pasien (23\%) dengan BTA positif, terbanyak pada jenis kelamin laki-laki dan kelompok usia 45-54 tahun.

\section{DAFTAR PUSTAKA}

1. Bab II pdf. 2017 Sept 28 [cited 2017 Aug 27]. Avaible from: http://www.etd.repository. ugm.ac.id/downloadfile/94326/.../S12016-315964-introduction.pdf

2. Kementerian Kesehatan RI Direktorat Jendral Pengendalian Penyakit dan Penyehatan Lingkungan. Pedoman Nasional Pengendalian Tuberkulosis. Jakarta: Kementerian Kesehatan RI, 2014.

3. Amin, Zulkifli, Bahar A. Tuberkulosis paru. In: Buku Ajar Ilmu Penyakit Dalam Jilid VI (5th ed). Jakarta: Pusat Penerbitan Ilmu Penyakit Dalam Fakultas Kedokteran Universitas Indonesia, 2014; p. 863-77.

4. Susanti D, Kountul C, Buntuan V. Pemeriksaan basil tahan asam (BTA) pada sputum penderita batuk $\geq 2$ minggu 
di Poliklinik Penyakit Dalam BLU RSUP Prof. Dr. R. D. Kandou Manado. eCl. 2013;1(1)

5. World Health Organization. Global Tuberculosis Report 2016. 2016 [cited 2017Sept 3]. Available from: http://www.searo.who.int/tb/documents/g lobal-tuberculosis-report-2016/en/

6. Pusat Data dan Informasi Kementrian Kesehatan RI. Data Informasi 2016 "Profil Kesehatan Indonesia". May 2016 [cited 2017 Sept 3]. Available from: www.depkes.go.id/folder/view/01/structu re-publikasi-pusdatin-info-datin.html

7. Badan Pusat Statistik Provinsi Sulawesi Utara. Sulawesi Utara dalam angka 2015. 2015 [cited 2017 Sept 4]. Available from: sulut.bps.go.id/new/backend2/pdf.../Sula wesi-Utara-Dalam-Angka-2015--.pdf

8. Ramalia MP, Porotu'o J, Homenta H. Hasil diagnostik Mycobacterium tuberculosis pada penderita batuk $\geq 2$ minggu dengan pewarnaan Ziehl-Neelsen di Puskesmas Ranomuut dan Puskesmas Kombos Manado. eBm. 2016;4(2).

9. Domu JR, Porotu'o J, Waworuntu OA, Ramalia MP, Heriyannis H. Hasil diagnostik mycobavterium tuberculosis pada penderita batuk $\geq 2$ minggu dengan pewarnaan ziehl-neelsen di Puskesmas Tuminting dan Puskesmas Tongkaina Manado. eBm. 2016;4(2).

10. Melawan penyakit TBC. 2014 March 24 [cited 2017 Aug 30]. Available from: http://www.sehatraga.com/melawanpenyakit-tbc/

11. Tabrani RH. Ilmu Penyakit Paru (1st ed). Jakarta: Trans Info Media, 2010; p. 15860.

12. Puspitasari P, Wongkar MCP, Surachmanto E. Profil pasien tuberkulosis paru di Poliklinik Paru RSUP Prof. Dr. R. D. Kandou Manado. eCl. 2014;2(1).
13. Sari ID, Mufingatul M, Sudibyo S. Hubungan pengetahuan dan sikap dengan kepatuhan berobat pada pasien TB paru yang rawat jalan di Jakarta tahun 2014. Medi Litbangkes. 2016;26(4):243-8.

14. Kolappan C, Gopi PG, Subramani, Narayanan PR. Selected biological and behavioural risk factors associated with pulmonary tuberculosis. Int $\mathrm{J}$ Tuberc Lung Dis. 2007;11(9):999-1003.

15. Masdar H. Pencegahan komplikasi tuberkulosis akibat pemberian TNF- $\alpha$ antagonis. Majalah Kedokteran Andalas. 2009;33(1):1-7.

16. Dotulong JF, Sapulete MR, Kandou GD. Hubungan faktor resiko umur, jenis kelamin, dan kepadatan hunian dengan kejadian TB. Jurnal Kedokteran Komunitas dan Tropik. 2015;3(2):57-64.

17. Rukmini, Chatarina UW. Faktor-faktor yang berpengaruh terhadap kejadian tb paru dewasa di indonesia (Analisis Data kesehatan dasar tahun 2010). Bul Penelit Sist Kesehat. 2011;14(4):320-31.

18. Munir SM, Nawas A, Soetyo DK. Pengamatan Pasien Tuberkulosis Paru dengan Mutidrug Resistant (TB-MDR) di Poliklinik Paru RSUP Persahabatan. J Respir Indon. 2010:30(2):92-104.

19. Negin J, Abimbola S, Marais JB. Tuberculosis among older adults. Int $\mathrm{J}$ Inf Dis. 2015;32:135-7.

20. Coffman J, Chanda-Kapata P, Marais JB, Kapata N, Zumla A, Negin J. Tuberculosis among older aldult in Zambia: burden and characteristics among a neglected group. BMC. 2017;17:804.

21. Eferia RN, Ramadhani Dian, Koralina Sherli, Indrriyani Fara, Rianti SSP, Yulia P. Jawetz, Melnck, and Adelberg Mikrobiologi Kedokteran (23rd ed). Jakarta: EGC, 2004; p. 40. 